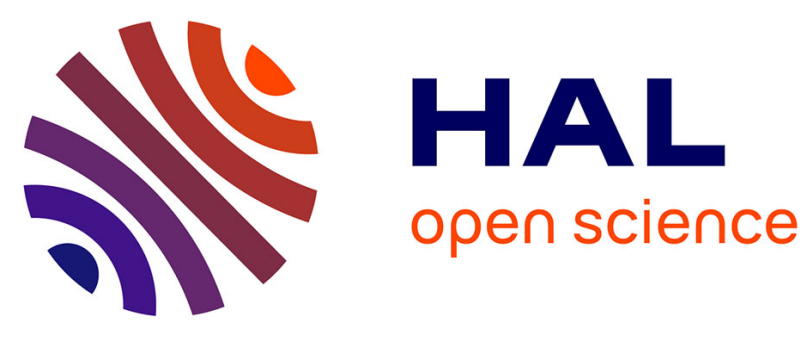

\title{
Induction of Immunogenic Tumor Cell Death by Attenuated Oncolytic Measles Virus
}

Carole Achard, Nicolas Boisgerault, Tiphaine Delaunay, Frédéric Tangy, Marc Grégoire, Jean-François Fonteneau

\section{- To cite this version:}

Carole Achard, Nicolas Boisgerault, Tiphaine Delaunay, Frédéric Tangy, Marc Grégoire, et al.. Induction of Immunogenic Tumor Cell Death by Attenuated Oncolytic Measles Virus. Journal of Clinical and Cellular Immunology, 2015, 6 (1), http://omicsonline.org/openaccess/induction-of-immunogenic-tumor-cell-death-by-attenuated-oncolytic-measles-virus-21559899-1000291.php?aid=38192． 10.4172/2155-9899.1000291． inserm-01148993

\section{HAL Id: inserm-01148993 https://www.hal.inserm.fr/inserm-01148993}

Submitted on 6 May 2015

HAL is a multi-disciplinary open access archive for the deposit and dissemination of scientific research documents, whether they are published or not. The documents may come from teaching and research institutions in France or abroad, or from public or private research centers.
L'archive ouverte pluridisciplinaire HAL, est destinée au dépôt et à la diffusion de documents scientifiques de niveau recherche, publiés ou non, émanant des établissements d'enseignement et de recherche français ou étrangers, des laboratoires publics ou privés. 


\title{
Induction of Immunogenic Tumor Cell Death by Attenuated Oncolytic Measles Virus
}

Carole Achard ${ }^{1-3}$, Nicolas Boisgerault ${ }^{1-3}$, Tiphaine Delaunay ${ }^{1-3}$, Frédéric Tangy ${ }^{4}$, Marc Grégoire ${ }^{1-3}$ and Jean-François Fonteneau ${ }^{1-3^{*}}$

${ }^{1}$ INSERM, UMR892, Institut de Recherche en Santé de l'Université de Nantes, France

${ }^{2}$ CNRS, UMR6299, Institut de Recherche en Santé de l'Université de Nantes, France

3 Université de Nantes, Nantes, France

${ }^{4}$ CNRS-URA 3015, Unité de Génomique Virale et Vaccination, Institut Pasteur, Paris, France

*Corresponding author: Jean-François Fonteneau, PhD, INSERM UMR892, CNRS UMR6299, Institut de Recherche Thérapeutique de I'Université de Nantes, 8 quai Moncousu, BP70721, 44007 Nantes, Cedex1, France, Tel: +33-228080239; Fax: +33-228080204; E-mail: jean-francois.fonteneau@inserm.fr

Received date: December 18, 2014, Accepted date: January 22, 2015, Published date: January 29, 2015

Copyright: ( 2015 Achard C, et al. This is an open-access article distributed under the terms of the Creative Commons Attribution License, which permits unrestricted use, distribution, and reproduction in any medium, provided the original author and source are credited.

\begin{abstract}
Antitumor virotherapy is a developing approach to treat cancer with oncolytic viruses, namely replicative viruses that exclusively or preferentially infect and kill tumor cells. Attenuated strains of Measles Virus (MV) are now being used as oncolytic viruses in clinical trials to treat several types of cancer. The efficacy of oncolytic viruses is mainly due to their capacity to infect and kill tumor cells, but it has also been demonstrated that their capacity to induce immunogenic cell death can activate an antitumor immune response. In this review, we describe the oncolytic capacity of MV and the concept of Immunogenic Cell Death (ICD). We then review how MV induces immunogenic cell death, which can be beneficial for cancer treatment.
\end{abstract}

Keywords: Measles virus; Virotherapy; Oncolytic viruses; Immunogenic cell death

\section{Introduction}

Antitumor virotherapy using replicative oncolytic viruses that exclusively or preferentially infect and kill tumor cells is a field that is growing rapidly, along with progress in molecular biological engineering [1]. These viruses are often derived from attenuated strains that either exhibit a natural tropism against tumor cells or that have been engineered to target tumor cells. Numerous RNA viruses (coxsackievirus, Newcastle Disease Virus (NDV), Vesicular Stomatitis Virus (VSV), Measles Virus (MV), poliovirus, and reovirus) and DNA viruses (adenovirus and vaccinia virus) are now being evaluated in clinical trials against a wide range of malignancies [1]. Adenovirus H101 is now approved in China for the treatment of head and neck cancer, and several other oncolytic viruses, such as HSV, adenovirus, and reovirus have entered phase III clinical trials [1].

\section{Attenuated MV as an Oncolytic Virus}

\section{Structure and replication cycle of MV}

Among oncolytic viruses, attenuated vaccine strains of MV show an interesting spontaneous tropism for infection and replication in tumor cells, and are now being evaluated for the treatment of several cancers. MV is a Morbillivirus of the Paramyxoviridae family, with an envelope and a negative, non-segmented, single-strand (ss) RNA genome [2]. The World Health Organization (WHO) indexes twenty-four strains of MV, classed into eight clades [3]. The MV RNA genome comprises around 16,000 nucleotides and encodes eight proteins. Two of these are non-structural proteins ( $\mathrm{V}$ and $\mathrm{C}$ ), expressed from an alternative RNA transcript encoding the phosphoprotein ( $\mathrm{P}$ protein). $\mathrm{V}$ and $\mathrm{C}$ protein are virulence factors, notably implicated in the inhibition of the innate intracellular immune defense, such as the type I Interferon (IFN) response. P protein, Large protein (L) and Nucleoprotein (N) form the nucleocapsid, which contains the viral ssRNA genome. The matrix $(\mathrm{M})$, fusion $(\mathrm{F})$, and hemagglutinin proteins $(\mathrm{H})$ form the viral envelope with lipids from the infected host cell membrane [2].

The replication cycle starts with the adsorption of MV onto the host cell membrane through the interaction between the $\mathrm{H}$ protein and the cell surface molecules, CD150, CD46, and/or Nectin-4 [4]. The F protein mediates the fusion between the viral particle and the host cell membrane, allowing the negative, single-stranded RNA and the associated proteins to penetrate into the cytoplasm. These proteins form a Ribo-Nucleo-Proteic (RNP) complex with the viral polymerase $\mathrm{L}$, which allows replication of the negative ssRNA and transcription of MV genes. The newly assembled viral particles bud from the infected cell plasma membrane, together with the matrix $(\mathrm{M})$ and the envelope glycoproteins (H,F). MV infection is known to induce the formation of syncytia. Indeed, MV-infected cells fuse with neighboring cells, thus forming multinucleated infected cells that increase the efficiency of MV replication.

\section{Oncolytic activity of MV}

MV uses several receptors to enter cells. The pathogenic wild-type (wt) strains use the signaling lymphocyte activation molecule (SLAM/ $\mathrm{CD} 150$ ), which confers to this virus a natural tropism for $\mathrm{T}$ and $\mathrm{B}$ lymphocytes and activated monocytes/macrophages [5,6]. This receptor usage explains the reports of spontaneous remission of leukemia and lymphoma in patients who have contracted a wt-MV infection [7-10]. These reports constitute the first proof of concept that MV can be used as a natural oncolytic virus.

Since 2001, the oncolytic activity of attenuated strains of MV has been reported, both in vitro, and in vivo in immunodeficient mice bearing human tumor xenografts. This activity has been demonstrated 
against T-cell lymphoma [11,12], myeloma [13], sarcoma [14], pancreatic cancer [15], glioblastoma [16], glioma [17], ovarian carcinoma [18], prostate cancer [19], breast cancer [19-21], melanoma [22], renal cell carcinoma [23], mesothelioma [24,25], medulloblastoma [26,27], hepatoblastoma [28], and lung/colorectal adenocarcinoma [29].

Attenuated vaccine strains of MV, such as Schwarz and Edmonston, which are spontaneously oncolytic, use the CD46 molecule as the major cell receptor [30-32]. The membrane cofactor protein, CD46, is an inhibitory complement receptor. Its expression at low density by healthy cells protects normal tissues from accidental injury by activated complement. Interestingly, many tumor types overexpress CD46 to escape complement-dependent cytotoxicity $[33,34]$. This selective overexpression by many cancer cell types confers on attenuated MV a natural tropism for tumor cells. Above a certain threshold of CD46 expression, the killing and syncytium formation mediated by MV infection increase dramatically [30], whereas healthy tissues with a low density of CD46 remain unharmed [18].

Recently, Nectin-4 (PVRL4) has been identified as a novel receptor for wild-type and attenuated strains [35,36]. This molecule plays a crucial role in the shedding of MV from the respiratory tract of infected individuals for transmission of the disease [37]. In humans, Nectin- 4 is mostly expressed in placenta and trachea, and at a lower level in tonsil epithelial cells, oral mucosa, lung macrophages, and neuronal cells of the cerebral cortex [35]. It is also frequently overexpressed in many adenocarcinomas, such as lung, ovarian, colon, and breast tumors [38-40]. Nectin-4 is used by MV for the infection of breast tumor cells [20].

Overexpression of MV receptors is probably not the only factor that determines the ability of MV to replicate and preferentially kill tumor cells. There is now evidence that host translational control of viral replication, and the incapability of some tumor cells to develop a type I interferon innate immune response, affect the oncolytic activity of MV $[14,41,42]$. All nucleated cells are equipped with intracytoplasmic sensors that are considered as Pathogen Recognition Receptors (PRR) and are able to detect viral infection [43]. In the case of MV, helicases such as the Retinoic acid-Inducible Gene 1 (RIG-I) and the Melanoma Differentiation-Associated protein 5 (MDA5) detect viral RNA and induce the secretion of type I IFN, which protects infected and neighboring cells from viral replication. Indeed, exposure to type I IFN induces the expression of numerous Interferon Sensitive Genes (ISG) that inhibit several stages of viral replication [44]. However, there are often defects of type I interferon response in tumor cells, to avoid the triggering of this response by frequent aberrant RNA transcripts present in these cells $[45,46]$. It allows the tumor cells to avoid induction of apoptosis or stimulation of antitumor immune response by the type I IFN.

\section{Clinical trials with oncolytic MV}

MV is now being evaluated, in clinical trials being carried out at the Mayo Clinic, for the treatment of several malignancies: ovarian cancer, mesothelioma, multiple myeloma, glioma, and squamous cell carcinoma of the head and neck [1]. A major asset for the clinical use of attenuated $\mathrm{MV}$ is its excellent safety profile, proven after the vaccination of millions of children over the past forty years, with no observed reversion to the wt-MV [47]. To date, the results of three clinical trials have been published, for the treatment of cutaneous $\mathrm{T}$ cell lymphoma (CTLC), chemoresistant ovarian cancer, and advanced multiple myeloma, with encouraging results and limited adverse effects [48-50]. Heinzerling and colleagues carried out the first phase I clinical trial of MV antitumor virotherapy using the EdmonstonZagreb strain of MV in five patients with CTCL [48]. This clinical study showed that intratumoral injection of MV after systemic treatment with IFN- $\alpha$ (to limit infection of healthy cells) induced local infection and a characteristic cytopathogenic effect of MV on tumor cells, leading to tumor regression in three patients.

MV was also evaluated by intraperitoneal injection for the treatment of patients with taxol- and platinum-refractory ovarian cancers, who were seropositive for measles virus to assure the safety of the trial. In this phase I clinical study, Evanthia Galanis and colleagues used MV-CEA, a modified Edmonston strain that produces the carcinoma embryonic antigen (CEA) as a soluble maker [49]. Indeed, CEA allows the monitoring of MV replication by serum dosage. Escalating doses were given to patients, ranging from $10^{3}$ to $10^{9}$ TCID50, with no observed dose-limiting toxicity. Clinical responses were observed in fourteen of twenty-one patients, notably disease stabilization, with a median duration of 92.5 days. Clinical response was associated with a diminution of the tumor-specific marker, CA-125, in five patients. Median survival time (12.15 months) was increased considerably compared to the expected median survival of the patient population (6 months).

More recently, a third phase I clinical trial was performed in two MV-seronegative patients with relapsing, drug-resistant, metastatic multiple myeloma [50]. These patients were given, by intravenous injection, a high dose (10 11 TCID50 infectious units) of Edmonston MV recombinant for the sodium/iodide symporter (NIS), which allows viral replication to be followed in vivo by radioiodine SinglePhoton Emission Computed Tomography (SPECT)-Computed Tomography (CT) imaging. Both patients responded to the treatment, with one experiencing a complete response during six months that is still on-going at the time of this publication.

\section{Immunogenic Cell Death (ICD)}

\section{Discovery of ICD}

Until the mid-1990s, it was thought that the major factor that conditions the induction of an immune response was the discrimination between "self" and "non-self". The presence of Pathogen-Associated Molecular Patterns (PAMPs) was necessary for the induction of an efficient immune response [51]. PAMPs are conserved molecular motifs specific to pathogens that are notably able to activate Antigen-Presenting Cells (APC) such as Dendritic Cells (DC), via PRR such as Toll-Like Receptors (TLR) [52]. When exposed to PAMPs, DC that capture antigens in peripheral tissues migrate to secondary lymphoid organs and initiate an adaptive immune response. PAMPs can also be detected during pathogen infection by intracytoplasmic PRR, which are expressed by all nucleated cells. This detection activates a cellular innate immune defense known as the type I IFN response that leads to secretion of type I IFN. These molecules act by autocrine and paracrine modes to block pathogen replication and eventually induce apoptosis.

The self/non-self-model fails, however, to explain why some microorganisms, such as commensal bacteria, are well tolerated, and why some self-constituents can trigger an immune response without the presence of pathogen, such as in the case of autograft. To take into account these phenomena, Poly Matzinger proposed the "danger theory", which postulates that the immune system does not concern so 
much with self and non-self, but rather detects situations that present danger [53]. Indeed, while apoptosis was considered to be nonimmunogenic, this theory implies that in certain conditions of stress, such as injury by pathogen, cell death can be accompanied by the release of cellular danger signals that are able to activate the immune system. These danger signals released during ICD activate APC, notably DC that, after capturing antigens, migrate to secondary lymphoid organs and initiate an adaptive immune response. Danger signals were later renamed Damage-Associated Molecular Patterns (DAMPs), as opposed to PAMPs [54]. The integration of both types of signals, DAMPs and PAMPs, induces and orients the immune response.

\section{Inducers and types of ICD}

Numerous inducers of ICD have now been described. Pathogens such as viruses can induce ICD [55]. Some chemotherapeutic drugs used for the treatment of cancer, such as doxorubicine, have also been shown to induce ICD [56]. In addition, some physical stimuli can induce ICD, such as ionizing radiation used in radiotherapy [57], ultraviolet-C irradiation [58], high hydrostatic pressure [59], hyperthermia $[60,61]$, and freeze/thaw cycles [62].

Different types of ICD have now been described [63]. Indeed, ICD can result from apoptosis accompanied by an endoplasmic reticulum (ER) stress and autophagy [64,65]. This form of apoptosis is characterized by preservation of cell membrane integrity with the formation of blebs, and by the release of DAMPs, such as highmobility group box 1 (HMGB1) protein and adenosine triphosphate (ATP), and the exposition of calreticulin on the surface of apoptotic cells. ICD can also result from pyroptosis, characterized by activation of the inflammasome that leads to the activation of caspase-1, able, notably, to transform pro-IL-1 $\beta$ into IL-1 $\beta$ [66]. Furthermore, pyroptosis is associated with the formation of cell-membrane pores that results in cell lysis. Pyroptosis is especially used by immune cells, such as neutrophils and leads to a rapid induction of inflammation in response to some pathogens. Necroptosis is an active necrosis program that can be induced notably by the presence of Tumor Necrosis Factor-alpha (TNF- $\alpha$ ) produced in response to a pathogen. TNF- $\alpha$ can trigger its receptor TNFR1 which lead to activation of receptorinteracting protein kinase 1 and 3 (RIPK1 and RIPK3). This signaling pathway will lead to necroptosis. This form of ICD is accompanied by the passive release of DAMPs such as HMGB1 and long genomic DNA, due to the loss of cell membrane integrity $[67,68]$. Finally, ICD can also result from passive necrosis induced by pathogen infection, toxin exposure, or physical trauma, and accompanied by the passive release of DAMPs such as HMGB1 and Heat Shock Proteins (HSP), and the exposure of F-actin $[68,69]$. Much work is still needed to understand the regulation of these different cell-death pathways and, importantly, their outcomes regarding the initiation and orientation of the immune response.

\section{DAMPs and ICD}

Several DAMPs have now been identified, and they exert various roles. Firstly, cells that undergo ICD expose, on their membrane, "eatme" signals for phagocytosis by APC. During ICD induced by ER stress and autophagy, calreticulin, which is normally located in the ER membranes, is rapidly exposed at the plasma membrane of apoptotic cells and can be recognized by scavenger receptors on APC [70,71]. During necrosis, F-actin is exposed to the extracellular environment and may also act as an "eat-me" signal for phagocytosis mediated by
DNGR1, also known as Clec9a in humans, a receptor found on DC that is specialized in cross-presentation [69]. Secondly, cells that undergo ICD can release some DAMPs that are implicated in the attraction and activation of immune cells. Among these, the firstdescribed DAMPs that are released during ICD, and that induce DC maturation, were from the HSP family, notably HSP70, HSP90, and gp96 [72]. Later, HMGB1, which is a nuclear protein that binds DNA, was reported as a major DAMP released during ICD that triggers activation of APC by several receptors, such as RAGE, TLR2, TLR4, TLR9, and TIM3 [73,74]. During ICD, ATP is another major DAMP that is released by dying cells and that attracts immune cells by triggering P2Y2 receptors [75] or P2X7 receptors [76]. Furthermore, ATP release during ICD has been shown to play a role in the induction of the antitumor immune response induced by some chemotherapeutic agents [77]. IL- $1 \beta$ is often considered as a DAMP released during pyroptosis following the activation of the inflammasome and caspase-1 [66]. IL-1 $\beta$ plays an important role in the inflammatory response.

\section{Oncolytic Measles Viruses and The Induction Of Tumor ICD}

\section{Evidence of ICD induction by MV from clinical trials}

The induction of immunogenic cell death by oncolytic viruses is probably an important parameter for their efficiency in antitumor virotherapy treatment $[1,78,79]$. As an example, it has been shown in a phase II clinical trial testing intratumoral injections of a modified oncolytic herpes simplex 1 virus in melanoma patients that tumors distant from the injection sites can regress, notably some visceral metastases [80]. In another phase II trial, injections of the oncolytic JX-594 vaccinia virus into treatment-refractory advanced hepatocellular carcinoma tumors also induced the regression of distant metastases [81]. The authors further showed that such treatment causes neutrophil infiltration into the injected tumor, an antibody response against tumor cells, and evidence of a cytotoxic T-cell response.

In the first phase I clinical trial using oncolytic MV, a positive effect on the antitumor response was reported [48]. In this trial, the Edmonston-Zagreb strain was used to treat five patients with cutaneous T-cell lymphoma. This study showed that intratumoral injections of MV after systemic treatment with IFN- $\alpha$ induced tumor regression in three patients. Interestingly, some regressions of distant lesions where MV was not injected were observed, suggesting that the treatment triggered the activation of an antitumor immune response. Furthermore, in a model of human lymphoma xenografts in immunodeficient mice, the injection of MV has been shown to induce tumor infiltration by activated neutrophils [82]. Altogether, these reports indicate that intratumoral MV injections can stimulate an antitumor immune response.

\section{Interaction of MV infected tumor cells and dendritic cells}

Our laboratory and others have been interested in characterizing, in vitro, how MV-infected tumor cells stimulate APC such as DC to induce their capacities to stimulate an adaptive antitumor immune response [22,25,83,84]. We first showed that MV infection of mesothelioma tumor cells induced ICD, in contrast with ultraviolet-B (UV-B) irradiation of tumor cells that undergo a nonimmunogenic cell death [25]. Indeed, MV-infected tumor cells induce the 
maturation of monocyte-derived DC, notably by the release of DAMPs such as HSP (HSP70, gp96), whereas apoptotic UV-B-irradiated tumor cells did not stimulate DC. We further showed that DC internalized materials from MV-infected tumor cells, notably tumor antigens such as mesothelin, and induced from naive lymphocytes a T-cell response directed against this tumor antigen. Altogether, these results not only show that MV kills tumor cells, but also that MV induces the release of tumor antigens allowing DC to cross-prime a specific $\mathrm{CD} 8^{+} \mathrm{T}$-cell response.

In 2011, Donnelly et al. confirmed that MV-infected tumor cells undergo ICD that is able to induce maturation of DC [22]. Furthermore, they identified the immunogenic factors released during ICD. They also showed that DC co-cultured with MV-infected melanoma tumor cells induces cytotoxic $\mathrm{T}$-cell responses against tumor cells. They identified numerous DAMPs and cytokines released by MV-infected tumor cells that make the cell death immunogenic. They showed that MV-infected cells release HMGB1 and numerous inflammatory cytokines, such as type I IFN (IFN- $\alpha$ and IFN- $\beta$ ), IL-6, IL-8, RANTES, and IL-28.

Plasmacytoid DC (pDC) is another type of DC specialized in antiviral immune response. Accumulating evidence suggests that it would be beneficial for cancer patients to stimulate this subset of DC within tumors, as these cells are able to induce an immune response by type I IFN production and antigen presentation, and can exert direct tumoricidal activity $[85,86]$. Conflicting reports have been published regarding the capacity of attenuated MV strains to stimulate IFN- $\alpha$ production by pDC $[87,88]$. Duhen et al. reported that attenuated strains of MV induce IFN- $\alpha$ secretion by $\mathrm{pDC}$, whereas Schlender et al. reported that they do not induce this secretion, but on the contrary inhibit it. We explained this discrepancy recently by investigating the activation of pDC in response to MV or MV-infected tumor cells [84]. We showed that pDC exposed to MV without IL-3, a survival factor that is required for in vitro culture of $\mathrm{pDC}$, do not produce IFN- $\alpha$ as reported by Schlender et al. [88], whereas pDC exposed to MV in the presence of IL-3 do produce IFN- $\alpha$ as reported by Duhen et al. [87]. We also observed that pDC exposed to MV-infected tumor cells produce huge amounts of IFN- $\alpha$ due to the triggering of TLR7 in the endosome by MV single-stranded RNA. Finally, we showed that, like monocyte-derived DC, pDC exposed to MV-infected tumor cells are able to internalize and cross-present tumor antigens such as NYESO-1 to $\mathrm{CD}^{+} \mathrm{T}$ lymphocytes to induce an antitumor immune response. In contrast, pDC exposed to UV-irradiated tumor cells keep an immature phenotype and are unable to cross-present the tumor antigen. Altogether, these studies show that MV infection of tumor cells induces an ICD that is able to activate tumor antigen crosspresentation function of both myeloid and plasmacytoid DC.

\section{The type of ICD induced by MV}

The type of ICD induced by MV infection of tumor cells is not well characterized. It is not yet described whether ICD is associated with ER stress and autophagy, pyroptosis, and/or necroptosis. It is now clear that HMGB1 is released from tumor cells following MV infection [22] (and unpublished personal data). These results suggest that it could be ICD accompanied by ER stress and autophagy or necroptosis. Infection by attenuated MV strains has recently been shown to induce autophagy in several waves [89,90]. The interaction of MV with CD46 receptors induces an early wave of autophagy followed by a second wave dependent on MV replication, and finally a third wave upon syncytium formation [90]. However, it is not clear from this study if autophagy participates in the induction of apoptosis, since the author states that this sustained autophagy flux is exploited by MV to limit the death of infected cells and to improve viral particle formation. More work is needed to better define which ICD pathways are induced by MV after the infection of tumor cells.

MV is known to trigger the antiviral type I IFN response in nucleated cells $[14,91,92]$. However, MV has evolved virulence factors, such as the V protein that inhibits type I IFN signaling at the level of STAT1 and STAT2 downstream of the type I IFN receptor, IFNAR [93,94]. The V protein also inhibits MDA5 signaling [95]. Another viral factor, the C protein of MV, blocks type I IFN signaling [96]. In attenuated MV such as Edmonston and Schwarz strains, the V protein carries a mutation that reduces its capacity to inhibit type I IFN signaling [97]. Thus, attenuated strains of MV do not completely inhibit the type I IFN response. Type I IFN produced by infected tumor cells or by pDC exposed to infected cells, can exert a diversity of beneficial effects on the antitumor immune response. IFN- $\alpha$ not only induces an antitumor cytotoxic activity of pDC by an autocrine loop, but can also act directly on tumor cells to induce apoptosis [98]. Type I IFN also play a role in NK activation and are required in a mouse model of NK-cell-dependent tumor rejection [99]. Type I IFN is also known to activate DC and their capacity to induce a cytotoxic T-cell response $[100,101]$. Thus, the triggering of type I IFN production by MV in infected tumor cells probably participates in the immunogenicity of cell death.

\section{Conclusion}

MV is a promising oncolytic virus that is currently being evaluated in phase I/II clinical trials. Its capacity to induce ICD, which probably participates in its oncolytic activity, is now proven. However, more studies are needed to better understand which ICD pathway is induced in tumor cells after infection. Apoptosis induced by oncolytic viruses is very specific to the virus type [1] and may be different from one tumor cell line to another, since these cells accumulate defects in antiviral innate response and apoptosis pathways. Finally, all the studies on MV-induced ICD suggest that it would be of interest to monitor the antitumor immune response after treatment of cancer patients by oncolytic MV to determine its importance in the efficacy of treatment.

\section{Acknowledgement}

This work has been supported by « la Ligue Régionale Grand Ouest contre le Cancer (CSIRGO) ", " the ARSMESO44 association ", " la Fondation du Souffle et le Fonds de Dotation Recherche en Santé Respiratoire ", " la Fondation pour la Recherche Médicale (FRM) ", and « la Fondation ARC pour la recherche sur le cancer».

\section{References}

1. Russell SJ, Peng KW, Bell JC (2012) Oncolytic virotherapy. Nat Biotechnol 30: 658-670.

2. Moss WJ, Griffin DE (2006) Global measles elimination. Nat Rev Microbiol 4: 900-908.

3. (2001) Nomenclature for describing the genetic characteristics of wildtype measles viruses (update). Wkly Epidemiol Rec 76: 249-251.

4. Bankamp B, Takeda M, Zhang Y, Xu W, Rota PA (2011) Genetic characterization of measles vaccine strains. J Infect Dis 204 Suppl 1: S533-548.

5. Hsu EC, Iorio C, Sarangi F, Khine AA, Richardson CD (2001) CDw150(SLAM) is a receptor for a lymphotropic strain of measles virus 
and may account for the immunosuppressive properties of this virus. Virology 279: 9-21.

6. Tatsuo H, Ono N, Tanaka K, Yanagi Y (2000) SLAM (CDw150) is a cellular receptor for measles virus. Nature 406: 893-897.

7. Bluming AZ, Ziegler JL (1971) Regression of Burkitt's lymphoma in association with measles infection. Lancet 2: 105-106.

8. Pasquinucci G (1971) Possible effect of measles on leukaemia. Lancet 1: 136.

9. Zygiert Z (1971) Hodgkin's disease: remissions after measles. Lancet 1: 593.

10. Ziegler JL (1976) Spontaneous remission in Burkitt's lymphoma. Natl Cancer Inst Monogr. 44: 61-65.

11. Parrula C, Fernandez SA, Zimmerman B, Lairmore M, Niewiesk S (2011) Measles virotherapy in a mouse model of adult T-cell leukaemia/ lymphoma. J Gen Virol 92: 1458-1466.

12. Grote D, Russell SJ, Cornu TI, Cattaneo R, Vile R, et al. (2001) Live attenuated measles virus induces regression of human lymphoma xenografts in immunodeficient mice. Blood 97: 3746-3754.

13. Peng KW, Ahmann GJ, Pham L, Greipp PR, Cattaneo R, et al. (2001) Systemic therapy of myeloma xenografts by an attenuated measles virus. Blood 98: 2002-2007.

14. Berchtold S, Lampe J, Weiland T, Smirnow I, Schleicher S, et al. (2013) Innate immune defense defines susceptibility of sarcoma cells to measles vaccine virus-based oncolysis. J Virol 87: 3484-3501.

15. Penheiter AR, Wegman TR, Classic KL, Dingli D, Bender CE, et al. (2010) Sodium iodide symporter (NIS)-mediated radiovirotherapy for pancreatic cancer. AJR Am J Roentgenol 195: 341-349.

16. Phuong LK, Allen C, Peng KW, Giannini C, Greiner S, et al. (2003) Use of a vaccine strain of measles virus genetically engineered to produce carcinoembryonic antigen as a novel therapeutic agent against glioblastoma multiforme. Cancer Res 63: 2462-2469.

17. Allen C, Opyrchal M, Aderca I, Schroeder MA, Sarkaria JN, et al. (2013) Oncolytic measles virus strains have significant antitumor activity against glioma stem cells. Gene Ther 20: 444-449.

18. Peng KW, TenEyck CJ, Galanis E, Kalli KR, Hartmann LC, et al. (2002) Intraperitoneal therapy of ovarian cancer using an engineered measles virus. Cancer Res 62: 4656-4662.

19. Iankov ID, Msaouel P, Allen C, Federspiel MJ, Bulur PA, Dietz AB et al. (2010) Demonstration of anti-tumor activity of oncolytic measles virus strains in a malignant pleural effusion breast cancer model. Breast Cancer Res Treat. 122: 745-754

20. Sugiyama T, Yoneda M, Kuraishi T, Hattori S, Inoue Y, et al. (2013) Measles virus selectively blind to signaling lymphocyte activation molecule as a novel oncolytic virus for breast cancer treatment. Gene Ther 20: 338-347.

21. McDonald CJ, Erlichman C, Ingle JN, Rosales GA, Allen C, et al. (2006) A measles virus vaccine strain derivative as a novel oncolytic agent against breast cancer. Breast Cancer Res Treat 99: 177-184.

22. Donnelly OG, Errington-Mais F, Steele L, Hadac E, Jennings V, et al. (2013) Measles virus causes immunogenic cell death in human melanoma. Gene Ther 20: 7-15.

23. Meng X, Nakamura T, Okazaki T, Inoue H, Takahashi A, et al. (2010) Enhanced antitumor effects of an engineered measles virus Edmonston strain expressing the wild-type N, P, L genes on human renal cell carcinoma. Mol Ther 18: 544-551.

24. Li H, Peng KW, Dingli D, Kratzke RA, Russell SJ (2010) Oncolytic measles viruses encoding interferon beta and the thyroidal sodium iodide symporter gene for mesothelioma virotherapy. Cancer Gene Ther 17: 550-558.

25. Gauvrit A, Brandler S, Sapede-Peroz C, Boisgerault N, Tangy F, et al. (2008) Measles virus induces oncolysis of mesothelioma cells and allows dendritic cells to cross-prime tumor-specific CD8 response. Cancer Res 68: 4882-4892.

26. Hutzen B, Pierson CR, Russell SJ, Galanis E, Raffel C, et al. (2012) Treatment of medulloblastoma using an oncolytic measles virus encoding the thyroidal sodium iodide symporter shows enhanced efficacy with radioiodine. BMC Cancer 12: 508.

27. Studebaker AW, Kreofsky CR, Pierson CR, Russell SJ, Galanis E, et al. (2010) Treatment of medulloblastoma with a modified measles virus. Neuro Oncol 12: 1034-1042.

28. Zhang SC, Wang WL, Cai WS, Jiang KL, Yuan ZW (2012) Engineered measles virus Edmonston strain used as a novel oncolytic viral system against human hepatoblastoma. BMC Cancer 12: 427.

29. Boisgerault N, Guillerme JB, Pouliquen D, Mesel-Lemoine M, Achard C, et al. (2013) Natural oncolytic activity of live-attenuated measles virus against human lung and colorectal adenocarcinomas. Biomed Res Int 2013: 387362 .

30. Anderson BD, Nakamura T, Russell SJ, Peng KW (2004) High CD46 receptor density determines preferential killing of tumor cells by oncolytic measles virus. Cancer Res 64: 4919-4926.

31. Dörig RE, Marcil A, Chopra A, Richardson CD (1993) The human CD46 molecule is a receptor for measles virus (Edmonston strain). Cell 75: 295-305.

32. Naniche D, Varior-Krishnan G, Cervoni F, Wild TF, Rossi B, et al. (1993) Human membrane cofactor protein (CD46) acts as a cellular receptor for measles virus. J Virol 67: 6025-6032.

33. Fishelson Z, Donin N, Zell S, Schultz S, Kirschfink M (2003) Obstacles to cancer immunotherapy: expression of membrane complement regulatory proteins (mCRPs) in tumors. Mol Immunol 40: 109-123.

34. Ravindranath NM, Shuler C (2006) Expression of complement restriction factors (CD46, CD55 \& CD59) in head and neck squamous cell carcinomas. J Oral Pathol Med 35: 560-567.

35. Noyce RS, Bondre DG, Ha MN, Lin LT, Sisson G, et al. (2011) Tumor cell marker PVRL4 (nectin 4) is an epithelial cell receptor for measles virus. PLoS Pathog 7: e1002240.

36. Mühlebach MD, Mateo M, Sinn PL, Prüfer S, Uhlig KM, et al. (2011) Adherens junction protein nectin- 4 is the epithelial receptor for measles virus. Nature 480: 530-533

37. Racaniello V (2011) Virology. An exit strategy for measles virus. Science 334: 1650-1651.

38. Derycke MS, Pambuccian SE, Gilks CB, Kalloger SE, Ghidouche A, et al. (2010) Nectin 4 overexpression in ovarian cancer tissues and serum: potential role as a serum biomarker. Am J Clin Pathol 134: 835-845.

39. Takano A, Ishikawa N, Nishino R, Masuda K, Yasui W, et al. (2009) Identification of nectin-4 oncoprotein as a diagnostic and therapeutic target for lung cancer. Cancer Res 69: 6694-6703.

40. Fabre-Lafay S, Garrido-Urbani S, Reymond N, Gonçalves A, Dubreuil P, et al. (2005) Nectin-4, a new serological breast cancer marker, is a substrate for tumor necrosis factor-alpha-converting enzyme (TACE)/ ADAM-17. J Biol Chem 280: 19543-19550.

41. Patel MR, Jacobson BA, Belgum H, Raza A, Sadiq A, et al. (2014) Measles vaccine strains for virotherapy of non-small-cell lung carcinoma. J Thorac Oncol 9: 1101-1110.

42. Noll M, Berchtold S, Lampe J, Malek NP, Bitzer M, et al. (2013) Primary resistance phenomena to oncolytic measles vaccine viruses. Int J Oncol 43: 103-112.

43. Ivashkiv LB, Donlin LT (2014) Regulation of type I interferon responses. Nat Rev Immunol 14: 36-49.

44. Mitchell PS, Emerman M, Malik HS (2013) An evolutionary perspective on the broad antiviral specificity of MxA. Curr Opin Microbiol 16: 493-499.

45. Katsoulidis E, Kaur S and Platanias LC (2010) Deregulation of interferon signaling in malignant cells. Pharmaceuticals. 3: 406-418.

46. Leonova KI, Brodsky L, Lipchick B, Pal M, Novototskaya L, et al. (2013) p53 cooperates with DNA methylation and a suicidal interferon response to maintain epigenetic silencing of repeats and noncoding RNAs. Proc Natl Acad Sci U S A 110: E89-98.

47. Lievano F, Galea SA, Thornton M, Wiedmann RT, Manoff SB, et al. (2012) Measles, mumps, and rubella virus vaccine (M-M-Râ, „II): a 
review of 32 years of clinical and postmarketing experience. Vaccine 30: 6918-6926.

48. Heinzerling L, Künzi V, Oberholzer PA, Kündig T, Naim H, et al. (2005) Oncolytic measles virus in cutaneous T-cell lymphomas mounts antitumor immune responses in vivo and targets interferon-resistant tumor cells. Blood 106: 2287-2294.

49. Galanis E, Hartmann LC, Cliby WA, Long HJ, Peethambaram PP, et al. (2010) Phase I trial of intraperitoneal administration of an oncolytic measles virus strain engineered to express carcinoembryonic antigen for recurrent ovarian cancer. Cancer Res 70: 875-882.

50. Russell SJ, Federspiel MJ, Peng KW, Tong C, Dingli D, et al. (2014) Remission of disseminated cancer after systemic oncolytic virotherapy. Mayo Clin Proc 89: 926-933.

51. Janeway C (1989) Immunogenicity signals $1,2,3 \ldots$ and 0 . Immunol Today 10: 283-286.

52. Kawasaki T, Kawai T (2014) Toll-like receptor signaling pathways. Front Immunol 5: 461.

53. Matzinger P (1994) Tolerance, danger, and the extended family. Annu Rev Immunol 12: 991-1045.

54. Seong SY, Matzinger P (2004) Hydrophobicity: an ancient damageassociated molecular pattern that initiates innate immune responses. Nat Rev Immunol 4: 469-478.

55. Guo ZS, Liu Z1, Bartlett DL1 (2014) Oncolytic Immunotherapy: Dying the Right Way is a Key to Eliciting Potent Antitumor Immunity. Front Oncol 4: 74.

56. Casares N, Pequignot MO, Tesniere A, Ghiringhelli F, Roux S, et al. (2005) Caspase-dependent immunogenicity of doxorubicin-induced tumor cell death. J Exp Med 202: 1691-1701.

57. Golden EB, Pellicciotta I, Demaria S, Barcellos-Hoff MH, Formenti SC (2012) The convergence of radiation and immunogenic cell death signaling pathways. Front Oncol 2: 88.

58. Brusa D, Migliore E, Garetto S, Simone M, Matera L (2009) Immunogenicity of 56 degrees $C$ and UVC-treated prostate cancer is associated with release of HSP70 and HMGB1 from necrotic cells. Prostate 69: 1343-1352.

59. Fucikova J, Moserova I, Truxova I, Hermanova I, Vancurova I, et al. (2014) High hydrostatic pressure induces immunogenic cell death in human tumor cells. Int J Cancer 135: 1165-1177.

60. Massé D, Ebstein F, Bougras G, Harb J, Meflah K, et al. (2004) Increased expression of inducible HSP70 in apoptotic cells is correlated with their efficacy for antitumor vaccine therapy. Int J Cancer 111: 575-583.

61. Shi H, Cao T, Connolly JE, Monnet L, Bennett L, et al. (2006) Hyperthermia enhances CTL cross-priming. J Immunol 176: 2134-2141.

62. Scaffidi P, Misteli T, Bianchi ME (2002) Release of chromatin protein HMGB1 by necrotic cells triggers inflammation. Nature 418: 191-195.

63. Inoue $\mathrm{H}$, Tani $\mathrm{K}$ (2014) Multimodal immunogenic cancer cell death as a consequence of anticancer cytotoxic treatments. Cell Death Differ 21: 39-49.

64. Kepp O, Menger L, Vacchelli E, Locher C, Adjemian S, et al. (2013) Crosstalk between ER stress and immunogenic cell death. Cytokine Growth Factor Rev 24: 311-318.

65. Ma Y, Galluzzi L, Zitvogel L, Kroemer G (2013) Autophagy and cellular immune responses. Immunity 39: 211-227.

66. Lamkanfi M, Dixit VM (2014) Mechanisms and functions of inflammasomes. Cell 157: 1013-1022.

67. Zou J, Kawai T, Tsuchida T, Kozaki T, Tanaka H, et al. (2013) Poly IC triggers a cathepsin D- and IPS-1-dependent pathway to enhance cytokine production and mediate dendritic cell necroptosis. Immunity 38: 717-728.

68. Kaczmarek A, Vandenabeele P, Krysko DV (2013) Necroptosis: the release of damage-associated molecular patterns and its physiological relevance. Immunity 38: 209-223.

69. Ahrens S, Zelenay S, Sancho D, HanÄ P, Kjẽ an evolutionarily conserved damage-associated molecular pattern recognized by DNGR-1, a receptor for dead cells. Immunity 36: 635-645.
70. Kepp O, Gdoura A, Martins I, Panaretakis T, Schlemmer F, et al. (2010) Lysyl tRNA synthetase is required for the translocation of calreticulin to the cell surface in immunogenic death. Cell Cycle 9: 3072-3077.

71. Obeid M, Tesniere A, Ghiringhelli F, Fimia GM, Apetoh L, et al. (2007) Calreticulin exposure dictates the immunogenicity of cancer cell death. Nat Med 13: 54-61.

72. Parmiani G, Testori A, Maio M, Castelli C, Rivoltini L, et al. (2004) Heat shock proteins and their use as anticancer vaccines. Clin Cancer Res 10: 8142-8146.

73. Apetoh L, Ghiringhelli F, Tesniere A, Obeid M, Ortiz C, et al. (2007) Toll-like receptor 4-dependent contribution of the immune system to anticancer chemotherapy and radiotherapy. Nat Med 13: 1050-1059.

74. Sims GP, Rowe DC, Rietdijk ST, Herbst R, Coyle AJ (2010) HMGB1 and RAGE in inflammation and cancer. Annu Rev Immunol 28: 367-388.

75. Elliott MR, Chekeni FB, Trampont PC, Lazarowski ER, Kadl A, et al. (2009) Nucleotides released by apoptotic cells act as a find-me signal to promote phagocytic clearance. Nature 461: 282-286.

76. Martins I, Tesniere A, Kepp O, Michaud M, Schlemmer F, et al. (2009) Chemotherapy induces ATP release from tumor cells. Cell Cycle 8: 3723-3728.

77. Michaud M, Martins I, Sukkurwala AQ, Adjemian S, Ma Y, et al. (2011) Autophagy-dependent anticancer immune responses induced by chemotherapeutic agents in mice. Science 334: 1573-1577.

78. Boisgerault N, Tangy F, Gregoire M (2010) New perspectives in cancer virotherapy: bringing the immune system into play. Immunotherapy 2 : 185-199.

79. Vacchelli E, Eggermont A, Sautès-Fridman C, Galon J, Zitvogel L, et al. (2013) Trial watch: Oncolytic viruses for cancer therapy. Oncoimmunology 2: e24612.

80. Senzer NN, Kaufman HL, Amatruda T, Nemunaitis M, Reid T, et al. (2009) Phase II clinical trial of a granulocyte-macrophage colonystimulating factor-encoding, second-generation oncolytic herpesvirus in patients with unresectable metastatic melanoma. J Clin Oncol 27: 5763-5771.

81. Heo J, Reid T, Ruo L, Breitbach CJ, Rose S, et al. (2013) Randomized dose-finding clinical trial of oncolytic immunotherapeutic vaccinia JX-594 in liver cancer. Nat Med 19: 329-336.

82. Grote D, Cattaneo R and Fielding AK (2003) Neutrophils contribute to the measles virus-induced antitumor effect: enhancement by granulocyte macrophage colony-stimulating factor expression. Cancer Res. 63: 6463-6468.

83. Fonteneau JF, Guillerme JB, Tangy F, Grégoire M (2013) Attenuated measles virus used as an oncolytic virus activates myeloid and plasmacytoid dendritic cells. Oncoimmunology 2: e24212.

84. Guillerme JB, Boisgerault N, Roulois D, Menager J, Combredet C, et al. (2013) Measles virus vaccine-infected tumor cells induce tumor antigen cross-presentation by human plasmacytoid dendritic cells. Clin Cancer Res. 19: 1147-1158.

85. Tel J and de Vries IJ (2012) Potential applications for plasmacytoid dendritic cells in cancer immunotherapy. Immunotherapy. 4: 979-982.

86. Tel J, Anguille S, Waterborg CE, Smits EL, Figdor CG, et al. (2014) Tumoricidal activity of human dendritic cells. Trends Immunol 35: 38-46.

87. Duhen T, Herschke F, Azocar O, Druelle J, Plumet S, et al. (2010) Cellular receptors, differentiation and endocytosis requirements are key factors for type I IFN response by human epithelial, conventional and plasmacytoid dendritic infected cells by measles virus. Virus Res 152: 115-125.

88. Schlender J, Hornung V, Finke S, Günthner-Biller M, Marozin S, et al. (2005) Inhibition of toll-like receptor 7- and 9-mediated alpha/beta interferon production in human plasmacytoid dendritic cells by respiratory syncytial virus and measles virus. J Virol 79: 5507-5515.

89. Joubert PE, Meiffren G, Grégoire IP, Pontini G, Richetta C, et al. (2009) Autophagy induction by the pathogen receptor CD46. Cell Host Microbe 6: 354-366. 
Citation: Achard C, Boisgerault N, Delaunay T, Tangy F, Grégoire M, et al. (2015) Induction of Immunogenic Tumor Cell Death by Attenuated Oncolytic Measles Virus. J Clin Cell Immunol 6: 291. doi:10.4172/2155-9899.1000291

Page 7 of 7

90. Richetta C, Grégoire IP, Verlhac P, Azocar O, Baguet J, et al. (2013) Sustained autophagy contributes to measles virus infectivity. PLoS Pathog 9: e1003599.

91. Delpeut S, Noyce RS, Siu RW, Richardson CD (2012) Host factors and measles virus replication. Curr Opin Virol 2: 773-783.

92. Naik S, Russell SJ (2009) Engineering oncolytic viruses to exploit tumor specific defects in innate immune signaling pathways. Expert Opin Biol Ther 9: 1163-1176.

93. Caignard G, Bouraï M, Jacob Y; Infection-MAPping project I-MAP Tangy F, Vidalain PO (2009) Inhibition of IFN-alpha/beta signaling by two discrete peptides within measles virus $\mathrm{V}$ protein that specifically bind STAT1 and STAT2. Virology 383: 112-120.

94. Caignard G, Guerbois M, Labernardière JL, Jacob Y, Jones LM; Infectious Mapping Project I-MAP, et al. (2007) Measles virus V protein blocks Jak1-mediated phosphorylation of STAT1 to escape IFN-alpha/beta signaling. Virology 368: 351-362.

95. Andrejeva J, Childs KS, Young DF, Carlos TS, Stock N, et al. (2004) The $\mathrm{V}$ proteins of paramyxoviruses bind the IFN-inducible RNA helicase, mda-5, and inhibit its activation of the IFN-beta promoter. Proc Nat Acad Sci U S A 101: 17264-17269.
96. Shaffer JA, Bellini WJ, Rota PA (2003) The C protein of measles virus inhibits the type I interferon response. Virology 315: 389-397.

97. Ohno S, Ono N, Takeda M, Takeuchi K, Yanagi Y (2004) Dissection of measles virus $\mathrm{V}$ protein in relation to its ability to block alpha/beta interferon signal transduction. J Gen Virol 85: 2991-2999.

98. Thyrell L, Erickson S, Zhivotovsky B, Pokrovskaja K, Sangfelt O, et al. (2002) Mechanisms of Interferon-alpha induced apoptosis in malignant cells. Oncogene 21: 1251-1262.

99. Swann JB, Hayakawa Y, Zerafa N, Sheehan KC, Scott B, et al. (2007) Type I IFN contributes to $\mathrm{NK}$ cell homeostasis, activation, and antitumor function. J Immunol 178: 7540-7549.

100. Diamond MS, Kinder M, Matsushita H, Mashayekhi M, Dunn GP, et al. (2011) Type I interferon is selectively required by dendritic cells for immune rejection of tumors. J Exp Med 208: 1989-2003.

101. Fuertes MB, Kacha AK, Kline J, Woo SR, Kranz DM, et al. (2011) Host type I IFN signals are required for antitumor CD8+ T cell responses through CD8\{alpha\}+ dendritic cells. J Exp Med 208: 2005-2016. 